\title{
I P Indonesian Journal of Pharmacology and Therapy The potential effect of natural compounds from Indonesian spices in alleviating inflammation due to the coronavirus disease (COVID-19): a narrative review
}

\author{
Yuliana \\ Department of Anatomy, Faculty of Medicine, Universitas Udayana, Denpasar, Bali, Indonesia \\ https://doi.org/10.22146/ijpther.2366
}

Submitted: $16 / 08 / 2021$

Accepted : 06/12/2021

Keywords:

capsaicin;

COVID-19;

curcumin;

allicin;

quercetin;

\section{ABSTRACT}

COVID-19 causes increasing of inflammatory cytokines even cytokine storm in the severe condition. Enhance body immune system is one strategy against COVID-19. Spices in traditional Indonesian cuisine are believed as boost immunity. They contain active compounds such as curcumin, allicin, quercetin and capsaicin which can be used to alleviate inflammation. In this literature review, the potency of curcumin, allicin, quercetin, and capsaicin in alleviating inflammation due the COVID-19 was reported. Literatures were gathered from PubMed, Science Direct, and Google Scholar search engines. COVID-19 causes the increase of proinflammatory cytokine levels such as TNF $\alpha$ and IL-6. Curcumin, allicin, quercetin, and capsaicin regulate the expression of proinflammatory cytokines. These nutritional agonists of peroxisome proliferator-activated receptor- $\gamma$ (PPAR- - ) showed inhibitory effects on pro-inflammatory cytokines and promote immune cell differentiation into anti-inflammatory phenotypes. Curcumin has an anti-inflammatory effect that can prevent pneumocytes, renal cells, and cardiomyocytes damages. Allicin and quercetin can decrease TNFa and IL-6 levels due to they can increase the superoxide dismutase (SOD) levels. In conclusion, curcumin, allicin, quercetin and capsaicin can enhance body immune system due to their anti-inflammatory effect through down-regulation of the inflammatory cytokines expression. These spices could be used as adjuvant therapy to boost body immune system against COVID-19.

\begin{abstract}
ABSTRAK
COVID-19 menyebabkan kenaikan sitokin inflamasi bahkan badai sitokin dalam kondisi yang parah. Peningkatan sistem imun tubuh adalah salah satu strategi melawan COVID-19. Rempah dalam masakan tradisional Indonesia dilaporkan dapat meningkatkan sistem imun. Rempah mengandung senyawa aktif seperti kurkumin, alisin, kuersetin, dan kapsaisin yang dapat digunakan untuk mengurangi inflamasi. Dalam kajian pustaka ini, potensi kurkumin, alisin, kuersetin, dan kapsaisin dalam mengurangi inflamasi akibat COVID-19 dilaporkan. Pustakan dikumpulkan dari PubMed, Science Direct, dan Google Scholar. COVID-19 menyebabkan kenaikan kadar sitokin proinflamasi seperti TNF $\alpha$ dan IL-6. Kurkumin, alisin, kuersetin, dan kapsaisin mengatur ekspresi sitokin proinflamasi. Nutrisi yang merupakan agonis peroxisome proliferatoractivated receptor- $\gamma$ (PPAR- - ) ini menunjukkan efek penghambatan pada sitokin proinflamasi dan memicu diferensiasi sel imun menjadi sel antiinflamasi. Kurkumin mempunyai efek antiinflamasi yang dapat mencegah kerusakan pneumosit, sel ginjal, dan kardiomiosit. Alisin dan kuersetin dapat menurunkan kadar TNF $\alpha$ dan IL-6 karena dapat meningkatkan kadar superoxide dismutase (SOD). Dapat disimpulkan, kurkumin, alisin, kuersetin dan kapsaisin dapat meningkatkan system imun tubuh karena efek antiinflamasinya melalui penurunan regulasi ekspresi sitokin inflamasi. Rempah ini dapat digunakan sebagai terapi tambahan untuk meningkatak sisitem imun melawan COVID-19.
\end{abstract}




\section{INTRODUCTION}

The first case of COVID-19 was reported in Wuhan, Hubei Province, China in December 2019. At first, the World Health Organization announced it as an epidemic. However, when the mortality rate was increased and the affected countries were getting more, the WHO declared it as a global pandemic on March $11^{\text {th }}$, 2020.1,2 The corona virus sufferers are getting more and more everyday. ${ }^{3}$ It spreads from Wuhan to other countries in the world. It is also complicated by the high-level of influenza like illnesses. ${ }^{4}$

In Indonesia, the COVID-19 outbreak started with the case of two people from West Java Province. Their test results were positive for infection after contact with someone from Japan. The positive cases of COVID-19 infection increased until now. ${ }^{5}$ The death rate has risen sharply, therefore the Indonesian government implements large-scale social restrictions. ${ }^{6}$

Severe COVID-19 is characterized by a cytokine storm. A cytokine storm is an excessive immune response to a viral infection. It is often obtained in severe COVID-19. It is related to complications, mortality rate, and death. Therefore, managing the cytokine storm could help in alleviating the COVID-19 associated mortality rate. ${ }^{1}$ The key for fighting against the coronavirus is by strengthening the immune system by good nutritional intake. ${ }^{7}$ Spices are inexpensive and may have a potential role to alleviate the inflammatory process through their antioxidant mechanism. ${ }^{1}$

The cause of COVID-19 is severe acute respiratory syndrome coronavirus 2 (SARS-CoV-2), a novel human coronavirus. It is categorized as a zoonotic origin with bats as the reservoir host. The COVID-19 transmission is by direct or indirect contact from coughing, sneezing, or any droplets from the infected person, also from the dirty surfaces. Thelength of incubation is about 2-14 days. The symptoms of COVID-19 are fever, shortness of breath, cough, etc. Sometimes it remains asymptomatic.
Patients with comorbidities (diabetes, cancer, hypertension) might have a worse prognosis than normal healthy people. The COVID-19 infection might progress into pneumonia and acute respiratory distress syndrome (ARDS). In the later stage, it will develop into a multi-organ failure and death. ${ }^{1,8}$

The coronaviruses are one of the largest RNA viruses. ${ }^{9}$ The ' $S$ ' protein of coronavirus binds to host cells through the ACE2 receptor. The receptors are in the oral and nasal mucosa, lungs, intestine, stomach, bladder, heart, and kidney. The pathogenesis of COVID-19 can be divided into two categories, i.e. non-severe and severe. Severe clinical presentation is commonly found in the elderly, immune-compromised, and in those with pre-existing comorbidities. Viruses cause cell destruction through direct cytopathic effects and immune response mediated destruction. The cell lysis is mediated by immune destruction. ${ }^{10}$

In the non-severe stage, the coronavirus fuses with the host cell membrane. The virus enters inside the host cell through the airway epithelium. The virus undergoes multiplication inside the host cell. After that, the virus reaches the lower airway and alveoli. In people with good immunity, the multiplication and propagation of viruses are limited. The viral load is reduced. Therefore, recovery is reached within 2-3 weeks with mild symptoms. ${ }^{10}$

The severe stage of SARS-CoV-2 infection is characterized by the disorder of the immune system. The virus reaches the lower respiratory tract and penetrates the alveoli lead to viremia. The cell-mediated immunity then releases many pro-inflammatory cytokines such as interferon, interleukin, and tumor necrosis factor (TNF) and chemokines which cause cytokine storms in severe COVID-19. ${ }^{8,10}$ A cytokine storm is an excessive immune response to a viral infection. It is related to complications, mortality rate, and death. Therefore, managing the cytokine storm could help in alleviating the COVID-19 associated mortality rate. Spices are believed can 
alleviate the inflammatory process through their antioxidant mechanism. ${ }^{1}$

The body immune system must be strengthened anytime to against the COVID-19. Spices in traditional Indonesian cuisine can boost immunity. In this paper, we discussed curcumin (Curcuma longa, Linn.), allicin (Allium sativum Linn.), quercetin (Allium cepa Linn.), and capsaicin (Capsicum annum Linn.) in alleviating inflammation against the COVID-19. Those spices are the most commonly used in Indonesian cuisine.

\section{MATERIALS AND METHODS}

This is a narrative literature review. References were taken from PubMed and Google Scholar search engines. The keywords were capsaicin, curcumin, COVID-19, allicin, quercetin. Inclusion criteria were full text, review, and research. Exclusion criteria were only abstract and more than ten years of publication date. The screening was conducted by the title, abstract, and full text. Finally, there were 28 journals and 2 web pages.

The study selection began with the removal of duplicate records. The irrelevant literatures were excluded by screening the titles and abstracts. If the free full text is available in English or Indonesian, then the reading and selection would be continued. Otherwise, it would be removed. Full-text screening steps are reading the abstract and conclusion and examining the type of the text. Case reports and pre-print articles were excluded.

\section{RESULT AND DISCUSSION}

Many biological activities of active compounds isolated from spices in various countries have been published. However, this paper was focused on curcumin, allicin, quercetin, and capsaicin which a lot of reported can regulate the expression of inflammatory cytokines. These nutritional peroxisome proliferator-activated receptor- $\gamma$ (PPAR- $\gamma$ ) agonists showed inhibitory effects on pro-inflammatory cytokines and promote immune cell differentiation into anti-inflammatory phenotypes. ${ }^{1}$ Although, nutrition is not a drug for COVID-19. However, it plays important role in the maintenance of health against various diseases including COVID-19.

A healthy diet of nutrition can strengthen the immune system, reduce the risk of infectious disease, and also improve body metabolism. ${ }^{11}$ The good nutrition is important during the COVID-19 pandemic. Stress related to quarantine makes changes of nutritional habits. ${ }^{12}$ Nutrition should be our priority to boost our immune system against the virus. ${ }^{13}$ Nutritional problem usually happens in adolescent. ${ }^{14}$

\section{Curcumin}

Curcumin is major constituent of turmeric (Curcuma longa, Linn.) belonging to Zingiberaceae family which grows in every region in Asia such as Indonesia, India, and China. ${ }^{17}$ Turmeric is used for a long time ago in various traditional cuisine and medicines. Curcumin (77\%) is primary constituent of curcuminoids, followed by demethoxycurcumin (17\%), and bisdemethoxycurcumin(3\%)whichfound in the polyphenol form. ${ }^{1,15-18}$ Curcumin is 1.7-bis(4-hydroxy-3-methoxyphenyl)1.6-heptadiene-3.5-dione and also called diferuloylmethane. ${ }^{15}$ The chemical structure of the curcuminoids is presented in FIGURE 1 . $^{17}$ 
<smiles>COc1cc(/C=C/C(=O)/C=C(O)/C=C/c2ccc(O)c(OC)c2)ccc1O</smiles><smiles>COc1cc(/C=C/C(=O)CC(=O)/C=C/c2ccc(O)cc2)ccc1O</smiles>

Demethoxycurcumin<smiles>O=C(/C=C/c1ccc(O)cc1)CC(=O)/C=C/c1ccc(O)cc1</smiles>

FIGURE 1. The chemical structure of curcuminoids isolated from Curcuma longa Linn. ${ }^{17}$

Curcumin has various biological activities including anticancer, antiinflammatory, antidiabetic, antioxidant, antimicrobial, antiatherosclerosis, antiarthritic, antidepressant, antivirus, and antifungal.,17,19 Curcumin can also relieve gastrointestinal discomfort. Curcumin also has therapeutic potential for cardiovascular disease, bronchitis, asthma, and rheumatoid arthritis. ${ }^{20}$

Curcumin is a hydrogen donor that can scavenge of free radical and acts as antioxidant activity. Curcumin interacts with the transcription factors, growth factor, and cell signal transduction pathways. Curcumin can also inhibit reactive oxygen species (ROS) and homeostatic enzymes in time and concentration dependent. The oxidative stress and antioxidant activities of curcumin will change gene expression and inhibit apoptosis. ${ }^{17}$

Curcumin has alleviated some expression of inflammatory mediators in cystic fibrosis rat models. It also relieved lung injury in diabetic rat lungs. Asthma protection was also revealed by curcumin consumption. Neuroprotective effects were shown against cerebral injury via the downregulation of IL-8 and IL$1 \beta .{ }^{1}$ Curcumin inhibits leukotriene and prostaglandin synthesis, proliferation of lymphocytes, natural cell killer's activity. Curcumin might have mild estrogenic activity via its binds to estradiol and progesterone receptors.

Wound healing and inflammatory disorders can also be relieved by curcumin. ${ }^{1}$ Curcumin regulates the expression of numerous transcription factors, enzymes related to inflammation, cytokines, and adhesion molecules. The antiinflammatory is mediated by the induction of the PPARs- $\gamma$ up-regulation. This mechanism inhibits the expression of TNF- $\alpha$ and NF- $\kappa \mathrm{B}$, a pro-inflammatory mediator. ${ }^{8}$

Curcumin is an effective molecule against viral infection due to it can modulate several molecular targets during the infection process. Those molecules' targets are transcription, replication, protease inhibition, attachment inhibition, and inhibition of viral entry into the cells. Curcumin inactivates and attacks the viral structure. Curcumin has been studied for its effectiveness against the hepatitis $C$ virus (HCV), Epstein-Barr virus (EBV), human cytomegalovirus (HCV), influenza A virus, enterovirus 71, and respiratory syncytial virus. Curcumin is also effective against the SARS-CoV by 
inhibits the 3C-like protease (3CLpro), interacts with ACE-2 and S proteins. ${ }^{2,16}$ Curcumin is approved by the US Food and Drug Administration (FDA) as a natural product that has a high potential for coronaviruses.

Therearedifferentnanotechnological carriers in developing curcumin. The nanotechnological carriers are microemulsions, nanoemulsions, nanogels, liposomes, micelles, and nanoparticles. During the COVID-19 pandemic, there are at least three nanotechnological carriers found for curcumin products in the market, namely polymeric nanoparticles (Nanocurc ${ }^{\mathrm{TM}}$ ), nano micelles (Sinacurcumin ${ }^{\circledR}$ ), and liposomes (LipocurctM). However, few studies evaluated the efficacy of curcumin nanosystem in vivo for COVID-19 infection. ${ }^{16}$

A non-randomized clinical trial to evaluate effectiveness of an oral curcumin nanosystem in soft gel capsule preparation (Sinacurcumin ${ }^{\circledR}$ ) on mild to moderate COVID-19 patients was reported. This preparation containing $40 \mathrm{mg}$ of curcuminoids in nanomicelles was administered two times daily for 14 days. The results of preliminary study showed that Sinacurcumin ${ }^{\circledR}$ improved the recovery time of COVID-19 patients faster than without Sinarcurcumin ${ }^{\circledR}$. Further study was recommended using representative sample size with randomized clinical trial design.

Another study was conducted to investigate the effects of Sinarcurcumin on the modulation of inflammatory cytokines using a double-blind randomized clinical trial. The Sinacurcumin ${ }^{\circledR}$ (40 mg) was administered to COVID-19 patients four times daily for two weeks and compared with placebo as negative control. Cytokine serum levels and mRNA expression were determined using ELISA and RTPCR, respectively. The resultas showed that expression of IL-1 $\beta$ and IL- 6 mRNA was modulated by Sinacurcumin ${ }^{\circledR}$ in COVID-19 patients. It may improve outcomes and recovery time. ${ }^{3}$

Another study by Tahmasebi et al.21 found that there is an anti-inflammatory response in the COVID-19 patients who were given Sinacurcumin ${ }^{\circledR}$. The study revealed that Sinacurcumin $^{\circledR}$ could reduce the frequency of the Th17 cells. The responses of inflammation were also reduced in mild to severe COVID-19 infected patients. Sinacurcumin ${ }^{\circledR}$ could be considered as a modulator in improving the patient's condition during the inflammatory process. ${ }^{21}$ There was a study to evaluate the curcumin nanomicelles effectiveness. It also studies the effects of Sinacurcumin ${ }^{\circledR}$ for the COVID-19 treatment. However, there were no studies that had revealed the response of free or entrapped curcumin. The antiviral potential against SARSCoV-2 was not tested either. ${ }^{16}$

Curcumin is an active molecule for fighting infection, inflammation, cancer, and degenerative diseases. However, it is unstable in the cell. Curcumin has improved its bioavailability when it is in nanoformulation. It will enhance its stability and specificity. The stable curcumin molecules are made by modifying the methylenic position. The methylenic position could increase cellular stability. This special position could remodel the affinity toward DFGin inactive conformation of Hck. Hck has a potential role in cancer and viral infection. Hck regulates cell migration, differentiation, proliferation, and immune receptor signaling. Inhibition Hck in COVID-19 patients protected against lung injury. It also improved pulmonary function. ${ }^{22}$

Curcumin may have a broadspectrum antiviral activity with low toxicity. The pharmacological mechanism against SARS-CoV2 was proven through in silico studies. However, the in vivo antiviral activity of curcumin has not been studied, yet. curcumin nanocarriers are available in the market indicated for inflammatory agent not for antiviral agent. Nanosystems and nanoparticles were investigated because of the functional and possible antiviral synergy. Turmeric (C. longa extract) only contains less than $7 \%$ of curcumin concentration. Thus, it is not a proper medicine for COVID-19. It also lacks FDA approval. ${ }^{16}$ 


\section{Allicin}

Allicin is major constituent of Allium sativum L., a bulbous plant belonging to Liliaceae family. Alium sativum L. is widely used as a spice in many cuisines worldwide. Alium sativum L. also has been used for many years due to its medicinal properties in many countries around the world. Allicin is found in A. sativum L. together with another sulfur-containing compounds such as alliin, E-ajoene, diallyl sulfide etc. (FIGURE 2). Allicin is well known for its antimicrobial, immunomodulatory, antiinflammatory, and antitumor properties as well as antiviral potency.<smiles>C=CCS[S+]([O-])CC=C</smiles>

Allicin<smiles>C=CCS/C=C/CS(=O)CC=C</smiles>

E-Ajoene

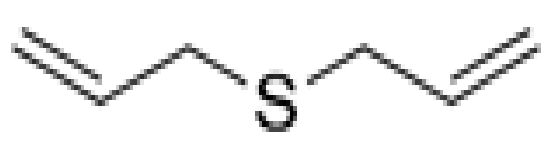

Diallyl sulfide<smiles>C=CCOSOCC=C</smiles>

Diallyl trisulfide<smiles>C=CCS(=O)CC(N)C(=O)O</smiles>

Alliin<smiles>C=CCSS/C=C\CS(=O)CC=C</smiles>

Z-Ajoene

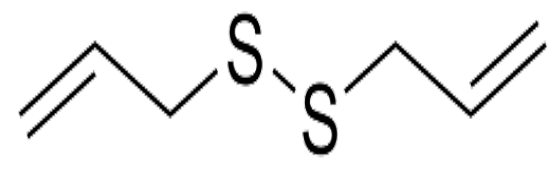

Diallyl disulfide

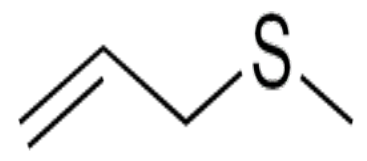

Allyl methyl sulfide

FIGURE 2. Chemical structure of allicin and sulfur-containing compounds isolated from $A$. sativum L.

Allicin could decrease the expression of pro-inflammatory cytokines. It could reverse the immunological abnormalities. It is suggested as a preventive measure for COVID-19 infection. Allicin is famous for its antimicrobial, immunomodulatory, anti-inflammatory, and antitumor properties. It also has antiviral potency. It is related to some immune leptin, leptin receptor, peroxisome proliferatoractivated receptor-gamma (PPAR-y) have been interpreted. Allium sativum L. can boost immune system cells. It represses the secretion of pro-inflammatory cytokines. $^{23}$
Allicin showed inhibition effects against allergic asthma in the in vivo study. It downregulated the levels of some cytokines such as IL-4, IL-5, Il-13 of the mice. It also decreased the levels of IL- 6 , TNF- $\alpha$, and IL-1 $\beta$. Another sulfurcontaining compounds isolated from $A$. sativum L. such as diallyl disulfide and S-allyl-L-cysteine were also proven to have an anti-inflammatory action. In the in vivo study, S-allyl-L-cysteine can reduce the mRNA expression of fibrosis markers such as fibronectin, $\alpha$-smooth muscle actin ( $\alpha$-SMA), collagen-I, and-III. S-allyl-L-cysteine also downregulated the mRNA expression of markers regulating 
the inflammation process such as IL-6, TNF- $\alpha$, and IL-12p35. S-allyl-L-cysteine was also reported can suppress the Akt/ NF-кB pathway in the in vivo study. In addition, S-allyl-mercapto cysteine reveals potent anti-inflammatory, antioxidative, antifibrotic, and antimetastatic effects. It alleviates inflammation by showing inhibition effects on several pro-inflammatory cytokines such asl IL6 , TNF- $\alpha$, and IL-1 $\beta$ and suppresses the NF- $\kappa B$ pathway in the mice models. ${ }^{24}$

Allicin was reported to have antiviral activity against HSV-1 and -2, human rhinovirus type 2, and parainfluenza virus type $3 .{ }^{25}$ Allicin (organosulfur) and quercetin (flavonoid) could decrease the risks of viral infection caused by SARS-CoV-2. It may be due to their interaction with the $\mathrm{M}^{\text {pro }}$ protease. The encapsulation of those bioactive substances at the microsized and also nanosized particles could maintain oxidative stability. Besides, nanoparticles<smiles>O=c1c(O)c(-c2ccc(O)c(O)c2)oc2cc(O)cc(O)c12</smiles>

Quercetin<smiles>O=C1c2c(O)cc(O)cc2OC2(c3ccc(O)c(O)c3)c3ccc(O)cc3OC12O</smiles>

Alliuocide<smiles>CSCC(N)C(=O)O</smiles>

S-methyl-L-cystein

$$
\mathrm{H}_{3} \mathrm{C}^{-\mathrm{S}_{-}} \mathrm{S}^{-\mathrm{S}} \mathrm{CH}_{3}
$$

Dimethyl trisulfide could ensure biofunctionality, it also provides controlled release and delivery to the targeted sites. Therefore, the consumption of functional foods which contain encapsulated or free bioactive compounds containing allicin might have a potential role in reducing the incidence of COVID-19 infection. ${ }^{24}$

\section{Quercetin}

Quercetin is found in onion (Allium cepa L), a plant also belonging to Liliaceae family. Allium cepa L. is widely consumed due to its nutritional value. Onion is a long time used as traditional medicine. Allium cepa L. is believed has several beneficial medical properties such as cardioprotective, anticancer, antifungal, antimicrobial, antiviral, etc. Quercetin together with biological active compounds such as cycloalliin, alliuocide, $\mathrm{N}$-acethylcystein, etc. have been isolated from onion (FIGURE 3).<smiles>C[C@H]1C[S@@](C)(=O)C[C@H](C(=O)O)N1</smiles>

Cycloalliin<smiles>CC(=O)NC(CS)C(=O)O</smiles>

$\mathrm{N}$-acethylcystein<smiles>CCCS(=O)CC(N)C(=O)O</smiles>

S-propyl-L-cystein sulfoxide<smiles>CS(=O)CC(N)C(=O)O</smiles>

S-methyl-L-cystein sulfoxide

FIGURE 3. Chemical structure of quercetin and other active compounds isolated from $A$. cepa $\mathrm{L}$. 
Red onion extract decreased the levels of TNF- $\alpha$, IL-6, and IL-10. Whereas, quercetin, one of active compound from A. cepa L. showed protective effects against atherosclerosis in mice. Those protective effects are due to reactive oxygen species (ROS) suppression. Quercetin modulates the expression of superoxide dismutase (SOD), $\mathrm{H}_{2} \mathrm{O}_{2}$, malondialdehyde (MDA), and $\mathrm{O}_{2}$. Quercetin suppressed inflammation and apoptosis by regulating the PI3K/

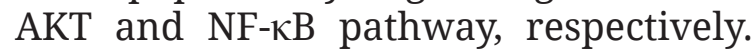
Quercetin also decreased IL-6 and TNF- $\alpha$ by increasing SOD levels. ${ }^{26}$

In silico studies have revealed that quercetin inhibits the entry of SARS$\mathrm{CoV}$ into the host cell by inhibiting the virus main protease $\left(\mathrm{M}^{\mathrm{pro}}\right)$. Therefore, quercetin might active against COVID-19 by reducing the length of SARS-CoV-2 infection. Quercetin is might useful as prophylactic use. Nevertheless, the preliminary evidence must be confirmed by randomized clinical trials to ensure its validity. ${ }^{26}$

\section{Capsaicin}

Capsaicin is major component of belle pepper (Capsicum annum L.) belonging to Solanaceae family.,11 Capsaicin with other derivatives such as hidydrocapsaicin, nordihydrocapsaicin, homodihydrocapsaicin and homocapsaicin have been isolated from bell pepper (FIGURE 4).<smiles>COc1cc(CNC(=O)CCCC/C=C/C(C)C)ccc1O</smiles>

Capsaicin<smiles>COc1cc(CNC(=O)CCCCCCC(C)C)ccc1O</smiles>

Dihydrocapsaicin<smiles>COc1cc(CNC(=O)CCCCCCCC(C)C)ccc1O</smiles>

Homodihydrocapsaisin<smiles>COc1cc(CNC(=O)CCCCCC(C)C)ccc1O</smiles>

Nordihydrocapsaicin<smiles>COc1cc(CNC(=O)CCCCC/C=C/C(C)C)ccc1O</smiles>

Homocapsaisin

FIGURE 4. Chemical structure of capsaicin and its derivatives isolated from Capsicum annum $\mathrm{L} .^{27}$

Capsaicin is widely used in many pharmaceutical formulations to treat various human mild diseases. Capsaicin exerts antiviral properties by reducing recurrent infection of the herpes simplex virus. Another study in Australia reported that there is a relationship between influenza A virus inhibition in the lungs with capsaicin intake. ${ }^{11}$ Capsaicin acts as an agonist at vanilloid receptor-1 of dendritic cells and enhance the antiviral activity of $\mathrm{CD}^{+}$cytotoxic T-cells. Studies in China reported the possible therapeutic role of traditional Chinese medicines in the treatment of COVID-19. ${ }^{1}$

Capsaicin has anti-inflammatory properties by reducing the expression of the pro-inflammatory cytokines such as IL- 6 and TNF- $\alpha$. In addition, capsaicin showed protective effects on the liver by decreasing the concentration of MDA in 
the liver. Malondialdehyde is a specific marker for peroxidation of the lipid, together with aspartate transaminase (AST) and alanine aminotransferase (ALT) as the markers for liver damage. Capsicum alleviated the increasing levels of cytosolic $\mathrm{Cu}-\mathrm{Zn}-\mathrm{SOD}$ and the mitochondrial in Mn-SOD. The extract of capsicum increases the concentration of Thtype 2 cytokines, namely IL-4, IL-5,IL-13 in the mouse models of asthma. Capsaicin inhibits the lipopolysaccharide (LPS)induced production of TNF- $\alpha$ by PPAR- $\gamma$ activation. It is a naturally occurring ligand for PPAR- $\gamma$. It can stimulate antiinflammatory mechanisms. ${ }^{1}$

Capsaicin exerts protective activities against diabetes, cancer, asthma, etc. It reduces inflammation by decreasing the levels of IL-6, TNF- $\alpha$, and IL-1 $\beta$. Capsaicin has a potential role in enhancing the expressions of liver $\mathrm{X}$ receptor- $\alpha$ $(\mathrm{LXR}-\alpha)$. It is done through the PPAR $\gamma$ pathway. Capsaicin can attenuate the inflammation of the salivary glands. It decreases the mRNA expression and protein expressions such as IL-6 and TNF- $\alpha$. Capsaicin decreases the concentration of IL-6, TNF- $\alpha$, and IL-1 $\beta .^{1}$

\section{The consuming of Indonesian spices during the COVID-19 pandemic}

Indonesian spices are well known worldwide due to their wide variety. They are not only used as cooking spices, but also as medicines. It is believed that the spices can be used to maintain of a healthy. During pandemic, the use of the spices as herbal medicines for the treatment of COVID-19 significantly increased in some countries in the world including in Indonesia. However, the data of the herbal consuming in the health care services during the COVID-19 pandemic in Indonesia is limited. The use of the herbal medicines as an adjuvant for the treatment of COVID-19 in the health care services should be approved by the National Agency of Drug and Food Control (NADFC), Republic of Indonesia. Therefore, the use of the herbal medicines is limited by the individually patients with COVID-19 in community.

The Government has encouraged people to use the Indonesian spices in order to enhance the body immune systemagainst the COVID-19. The Ministry of Health supported the use traditional medicine to maintain, prevent and care of health during COVID-19 pandemic. Some formulation of herbal medicines have recommended to be used including $C$. longa L. and $A$. sativum L. ${ }^{28}$ Furthermore, the NADFC was also launched the books containing information concerning traditional medicines and health supplements against COVID-19 such as the Guideline of Use Herbal and Health Supplements Against COVID-19, the E-book of Informatorium of the Original Indonesian Modern Medicine during COVID-19 Pandemic and the Handbook of Traditional Medicine for Enhance Body Immune System. ${ }^{29}$

Some researchers from Universities have also involved in the encourage the use of traditional medicine during COVID-19 pandemic. Krisnawan et al. ${ }^{30}$ implemented a program of community empowerment in Denpasar aimed to spread the skills of making functional drinks from Indonesian herbal as immune booster. Furthermore, Sunadi et al. ${ }^{31}$ trained the community in Denpasar City in the good and healthy preparing of functional drinks from C. longa L during COVID-19 pandemic. Tuloli and Taufik ${ }^{32}$ conducted the Thematic Community Program aiming empowering and utilization of family medicinal plant (TOGA) for immunostimulant beverage product during COVID-19 pandemic in Wubudu Village in Gorontalo District.

\section{CONCLUSION}

In conclusion, curcumin, allicin, quercetin and capsaicin can enhance body immune system due to their antiinflammatory effect through downregulation of the inflammatory cytokines expression. These spices could be used as adjuvant therapy to boost body immune system against COVID-19. However, their use is still based on the empirical and preclinical studies. Further clinical study should be performed in order to prove their clinical efficacy. 


\section{ACKNOWLEDGEMENT}

The author has no conflicts of interest to declare.

\section{REFERENCES}

1. Kunnumakkara AB, Rana V, Parama D, Banik K, Girisa S, Sahu H, et al. COVID-19, cytokines, inflammation, and spices: How are they related? Life Sci 2021; 284: 119201. https://doi.org/10.1016/j.lfs.2021.119201

2. Zhu N, Zhang D, Wang W, Li X, Yang $\mathrm{B}$, Song J, et al. A Novel coronavirus from patients with pneumonia in China, 2019. New Engl J Med 2020; 382(1):727-33.

https://doi.org/10.1056/NEJMoa2001017

3. Utamayasa IGD. Effect physical activity and nutrition during the COVID-19 pandemic. Int J Eng Sci Inf Technol 2021; 1(1):52-4.

https://doi.org/10.52088/ijesty.v1i1.58

4. Bogoch II, Watts A, Bachli AT, Huber C, Kraemer MUG, Khan K. Pneumonia of unknown etiology in Wuhan, China: potential for international spread via commercial air travel. J Travel Med 2020; 272(1):1-3.

5. Rachman BE, Rusli M, Miftahussurur M. The hidden vulnerability of COVID-19 observed from asymptomatic cases in Indonesia. Sys Rev Phar 2020; 11(2):703-13. htpps://doi.org/10.31838/srp.2020.2.103

6. Suni NSP. Tingginya kasus aktif dan angka kematian akibat COVID-19 di Indonesia. Bid Kesejaht Sos Info Singk Kaji Singk terhadap Isu Aktual dan Strateg. 2021; XIII(3):13-8. Cite from: https:berkas.dpr.go.id/puslit/ files/info_singkat/Info Singkat-XIII-3I-P3DI-Februari-2021-1957.pdf

7. Naja F, Hamadeh R. Nutrition amid the COVID-19 pandemic: a multilevel framework for action. Eur J Clin Nutr 2020; 74(1):1117-21.

https://doi.org/10.1038/s41430-0200634-3

8. Ciavarella C, Motta I, Valente S, Pasquinelli G. Agonists of PPAR- $\nu$ as candidates for cytokine storm modulation in COVID-19 disease
Molecules 2020; 25:1-15.

h t t p s://d o i.org/10.3390/ molecules25092076

9. Woods JA, Hutchinson NT, Powers SK, Roberts WO, Radak MCG-CZ, Berkes I, et al. The COVID-19 pandemic and physical activity. Sport Med Heal Sci 2020; 2(2):55-64.

h t tps://doi.org/10.1016/j . smhs.2020.05.006

10. Gautam S, Gautam A, Chhetri S, Bhattarai U. Immunity against COVID-19: potential role of Ayush Kwath. J Ayurveda Integr Med 2020; 1-8. https://doi.org/10.1016/j.jaim.2020.08.003

11. Kamyari N, Soltanian AR, Mahjub $\mathrm{H}$, Moghimbeigi A, Sina DA. Diet, nutrition, obesity, and their implications for COVID-19 mortality: development of a marginalized two-part model for semicontinuous data. JMIR Public Heal Surveill 2021; 7(1):1-16.

https://doi.org/10.2196/22717

12. Mattioli AV, Sciomer S, Cocchi C, Maffei S. Quarantine during COVID-19 outbreak: Changes in diet and physical activity increase the risk of cardiovascular disease. Nutr Metab Cardiovasc Dis 2020; 30(1):1409-17.

ht tps://doi.org/10.1016/j . numecd.2020.05.020

13. Mishra S, Patel M. Role of nutrition on immune system during COVID-19 pandemic. J Food Nutr Heal 2020; 3(2):1-6.

14. Tavakol Z, Ghannadi S, Tabesh MR, Halabchi F, Noormohammadpour P. Relationship between physical activity, healthy lifestyle and COVID-19 disease severity; a crosssectional study. Z Gesundh Wiss 2021; 1-6.

https://doi.org/10.1007/s10389-02001468-9

15. Hewlings SJ, Kalman DS. Curcumin: A review of its ' effects on human health. Foods 2017; 6(1):1-11. https://doi.org/10.3390/foods6100092

16. Dourado D, Freire DT, Pereira DT, Amaral-Machado L, Alencar EN, de Barros ALB, et al. Will curcumin nanosystems be the next 
promising antiviral alternatives in COVID-19 treatment trials? Biomed Pharmacother 2021; 139:1-7.

h t t p s://doi.org/10.1016/j . biopha.2021.111578

17. Abdurrahman N. Kurkumin pada Curcuma longa sebagai tatalaksana alternatif kanker. J Agromedicine 2019; 6(2):410-5.

18. Wahyuni WT, Darusman LK, Diksy Y. Deteksi kurkumin dan bisdemetoksikurkumin dengan teknik voltametri menggunakan elektrode boron-doped diamond. ALCHEMY J Penelit Kim 2018; 14(2):253-66.

h t t p s://doi.org/10.20961/ alchemy.14.2.19576.253-266

19. Rini CS, Rohmah J, Widyaningrum LY. Efektivitas kunyit (Curcuma longa Linn.) terhadap Escheerichia coli dan Bacillus subtilis. Medicra (Journal Med Lab Sci) 2018; 1(1):1-6. https://doi.org/10.21070/medicra. v1i1.1546

20. Selmanovic S, Beganlic A, Salihefendic N, Ljuca F, Softic A, Smajic E. Therapeutic effects of curcumin on ultrasonic morphological characteristics of liver in patients with metabolic syndrome. Acta Inform Med 2017; 25(3):169-74.

h t t p s: // d o i.org/ 10.5455 / aim.2017.25.169-174

21. Tahmasebi S, El MA, Zaid E, Mahmoud H, Varshoch M, Vaez A, et al. Immunomodulatory effects of nanocurcumin on Th17 cell responses in mild and severe COVID-19 patients. J Cell Physiol 2020; (December):1-14.

https://doi.org/10.1002/jcp.30233

22. Chakraborty MP, Bhattacharyya S, Roy S, Bhattacharya I, Das R, Mukherjee A. Selective targeting of the inactive state of hematopoietic cell kinase (Hck) with a stable curcumin derivative. J Biol Chem Res Artic 2021; 296:1-13.

https://doi.org/10.1016/j.jbc.2021.100449

23. Donma MM, Donma O. The effects of Allium sativum on immunity within the scope of COVID-19 infection. Med Hypotheses 2020; 144:1-6.

h t tps://d oi.org/10.1016/j . mehy.2020.109934

24. Khubber S, Hashemifesharaki R, Mohammadi M, Mohammad S, Gharibzahedi T. Garlic (Allium sativum L.): a potential unique therapeutic food rich in organosulfur and flavonoid compounds to fight with COVID-19. Nutr J 2020; 19(124):20-2.

https://doi.org/10.1186/s12937-02000643-8

25. Samaddar A, Gadepalli R, Nag VL, Misra S. The enigma of low COVID-19 fatality rate in India. Front Genet 2020; 11:1-9.

https://doi.org/10.3389/fgene.2020.00854

26. Brito JCM, Lima WG, Nizer WS da C. Quercetin as a potential nutraceutic against coronavirus disease 2019. Ars Pharm 2021; 62(1):85-9.

27. Fattori V, Hohmann MSN, Rossaneis AC, Pinho-Riberiro FA, Verri Jr WA. Capsaicin: Current understanding of its mechanisms and therapy of pain and other pre-clinical and clinical uses. Molecules 2016;21(844):1-33.

h t t p s : // d o i.org / 10.3390 / molecules21070844

28. Direktorat Jenderal Pelayanan Kesehatan. Surat Edaran Nomor: HK.02.02/IV.2243/2020 Tentang pemanfaatan obat tradisional untuk pemeliharaan kesehatan, pencegahan penyakit, dan perawatan kesehatan. Jakarta: Kementerian Kesehatan Republik Indonesia, 2021.

29. Badan Pemeriksa Obat dan Makanan, Republik Indonesia. Badan POM Tanggap COVID-19. Jakarta: Badan Pemeriksa Obat dan Makanan, Republik Indonesia. Available from: https://www.pom.go.id/new/view/ direct/hotissue-covid19

30. Krisnawan AH, Alkindi FF, Muttaqin D, Wahyudi ES. Pemberdayaan masyarakat dalam pemanfaatan tanaman herbal Indonesia sebagai minuman fungsional peningkat imunitas tubuh. Caradde: Jurnal 
Pengabdian kepada Masyarakat 2021; 4(1):163-72.

31. Sunadi IM, Wardani IGAAK, Ratnasari NLAM. Edukasi pemanfaatan toga untuk meningkatkan imunitas dimasa pandemi COVID-19 kepada Seka Truna-Truni Desa Kesiman Petila. Prosiding Seminar Regional Pengabdian Kepada Masyarakat Unmas Denpasar di Masa Pandemi
Covid-19 Tahun 2020. Denpasar: Universitas Mahasaraswati, 2020.

32. Tuloli TS, Taufik M. Pemberdayaan dan pemanfaatan tanaman TOGA untuk produk minuman immunostimulan di masa pandemi COVID-19 Desa Wubudu, Kecamatan Sumalata Timur, Kabupaten Gorontalo Utara. Laporan Akhir KKN Tematik. Gorontalo: Universitas Negeri Gorontalo, 2020. 